\title{
Monitoring Hepcidin Level in Chronic Hepatitis C Virus Patients during Therapy
}

\author{
Nashwa Khadr ${ }^{1}$, HadirOkasha ${ }^{1}$, Hanan Nouh ${ }^{2}$, Walaa Semary ${ }^{3}$ \\ ${ }^{I}$ Medical Microbiology and Immunology Department, Faculty of Medicine, University \\ of Alexandria, Egypt. \\ 2 Internal Medicine Department, Faculty of Medicine, University of Alexandria, Egypt. \\ ${ }^{3}$ Microbilogy Department, Ministry of Health, ElRaml Hospital ,Alexandria ,Egypt.
}

Corresponding Author:
Hadir Okasha

Phone :

+2035971675

E mail:

hadir.Okasha@alexme d.edu.eg

Key words: Hepcidin, $\mathrm{HCV}$, Hepatitis, Interferon
Introduction and study aim : Egypt has the highest prevalence of hepatitis $\mathrm{C}$ in the world estimated about $15 \%$. There are several host and viral factors that aid in predicting response to treatment, Hepcidine hormone is being investigated as one of these host factors.

The aim of the work is to assess the serum concentration of hepcidin in chronic hepatitis $\mathrm{C}$ patients and evaluate any possible association with the viral load during therapy.

Patients and methods: This study was carried on 35 chronic HCV patients on peg IFN/ Ribavirin therapy and 15 chronic HCV patients not on therapy as a control group.

Hepcidin hormone levels were measured in sera of patients before starting therapy (base line) then at 12 and 24 weeks during

\section{INTRODUCTION}

Hepatitis $\mathrm{C}$ virus (HCV) is a major health problem affecting 170 million people worldwide. The seroprevalence rate is about $1 \%$ in western countries and North America, 3-4\% in some Mediterranean and Asian countries and up to $10-20 \%$ in parts of central Africa [1,2]. It is estimated that Egypt comes first worldwide in $\mathrm{HCV}$ prevalence, with incidence rates at 2.4 per 1,000, and an estimated average of 165,000 new incidents per year, according to the Centers for Disease Control and Prevention (CDC) [3].Infection follows a variable course; while it is often asymptomatic , some patients develop liver fibrosis and ultimately cirrhosis, which is apparent after many years[4]. Making therapy. RT PCR was used to asses response to ongoing therapy.

Results: The level of hepcidin in all cases was low before starting therapy and it showed a significant increase during the course of therapy. This rise was detected earlier in responding cases. A negative correlation was found between baseline hepcidin level and baseline viral load of the responding cases.

Conclusion: Chronic HCV infection is associated with reduced level of serum hepcidin hormone. The reduced serum hepcidin in chronic HCV patients is fully reversible after IFN/RBV therapy. Initial rise in serum hepcidin concentration might have a potential for being used as one of the indicators of patient response to therapy.

HCV infection the leading cause of chronic hepatitis worldwide, where resolution of acute hepatitis is observed only in $15 \%$ and chronic infection develops in $85 \%$ of infected cases, progression to liver cirrhosis is seen in approximately $20 \%$ of patients after 10 years and to hepatocellular carcinoma (HCC) in a subset of them with a yearly incidence of $3 \%$ $[5,6]$.The liver is a large, complex organ that is responsible for synthesizing and secretion of bile ,lipoproteins and plasma proteins, including clotting factors. Liver disease is often reflected by biochemical abnormalities of liver functions [7]. Out of the noninvasive markers of hepatic fibrosis that are recently being evaluated for their 
ability to assess liver condition; is Hepcidin[8,9]. Hepcidin was first discovered in human blood ultrafiltrate and urine samples as a small bactericidal peptide (defensin and cathelicidin) and named liver-expressed antimicrobial peptide (LEAP-1) $[8,9]$. The name 'hepcidin' originates from the place of synthesis in hepatocytes (hep) and its antimicrobial activity (cidin). It has antibacterial (Escherichia coli, Staphylococcus aureus, Staphylococcus epidermidis, Streptococcus spp. group B) and antifungal activity (Candida albicans, Aspergillusniger, Aspergillusfumigatus) [10].

Recent work has also established the importance of the peptide hepcidin in iron homeostasis as a negative regulator of iron release into the system by duodenal enterocytes and reticuloendothelial macrophages [11, 12].

Hepcidin binds to the iron exporter ferroportin, which results in ferroportin internalization and degradation [13,14,15]. Explaining why iron accumulation in the liver is common in patients with chronic liver disease, as it is present in $10 \%$ to $36 \%$ of patients with chronic hepatitis C [16] and is even more common among patients with end-stage liver disease due to hepatitis C $[17,18]$.

In addition to its antibacterial effect and its role in iron homeostasis, hepcidin was also found to be induced by inflammation [14], an effect believed to be dependent on cytokine production [15].

The discovery of hepcidin in 2000[19] not only opened the way to understand its antimicrobial and metabolic role but also raised the question of the use of hepcidin as a diagnostic and therapeutic tool in many diseases.

This study aimed to assess the serum concentration of hepcidin in chronic hepatitis C patients and evaluate any possible association with the disease activity during the first 24 weeks of pegylated IFN and Ribavirin therapy.

\section{PATIENTS AND METHODS}

This study was carried on 35 newly diagnosed chronic HCV patients enrolled in the National Control Strategy Program for Viral Hepatitis Treatment[20], after the first 12 weeks of therapy, five patients were still positive for $\mathrm{HCV}$ RNA and were excluded from the treatment program. So, only 30 patients continued in the treatment program. Also Fifteen chronic HCV patients not on IFN therapy were included in the study as controls to determine their serum hepcidin levels.

The study was approved by the Alexandria Faculty of Medicine Ethical committee and informed consent was obtained from patients before sampling.

All patients were diagnosed as chronic HCV through the presence of $\mathrm{HCV}$ antibodies in their sera for at least 6 months and presence of $\mathrm{HCV}$ RNA by quantitative real-time RT-PCR. Liver biopsy was done in order to assess the degree of liver fibrosis according to Metavir scoring system, and non of the included patients had liver cirrhosis, HBV, HDV nor HIV co-infections.

Patients received a combination therapy of: weekly dose of PEG-IFN- $\alpha 2 b$ (PEG-INTRON) administered subcutaneously at a dose $(1.5 \mu \mathrm{g} /$ $\mathrm{kg}$ /week), and RBV administered orally at daily doses of $10.6 \mathrm{mg} / \mathrm{kg} / \mathrm{day}$ (1000-1200 mg/day).

All patients were subjected to routine base line laboratory investigation including [21] :

1- Liver function test (ALT,AST,Serum Albumin).

2- Alkaline phosphatase.

3- Serum bilirubin.

4- Haemoglobin concentration.

5- Liver biopsy to assess degree of fibrosis.

6- Real Time PCR for serum HCV RNA level was done before PEG-IFN- $\alpha$ RBV therapy and then at week 12 and week 24 during therapy using COBAS TaqMan HCV assay (TaqMan) (Roche Diagnostics). The COBAS AmpliPrep/COBAS TaqMan HCV test utilizes automated specimen preparation on the COBAS AmpliPrep Instrument then the processed specimen is added to the amplification mixture and transferred to the COBASTaqMan 48 Analyzer according to manufacturer instructions [22].

7- Detection of serum Hepcidin concentration before and during PEG-IFN- $\alpha$ / RBV therapy and at week 12 and week 24 of therapy for the 30 cases that achieved EVR and for the control group which was done at the beginning of the study and at the end of the six month which is the period of the study.

\section{Hepcidin hormone measurement :}

Blood samples were collected from patients by venipuncture at the beginning of therapy, then at 12 weeks and 24 weeks during therapy. Three $\mathrm{ml}$ blood were collected and allowed to clot for two hours at room temperature before centrifugation for 20 minutes at approximately $1000 \mathrm{xg}[23,24]$. 
Then serum was removed and stored at $-80^{\circ} \mathrm{C}$ to avoid loss of bioactivity or contamination.

Serum Hepcidin (HEPC) concentrations was measured using the quantitative sandwich enzyme immunoassay kit (USCN, Life Science Inc. Wuhan, China) according to manufacturer instructions.

The HEPC enzyme linked immunosorbent assay is quantitative sandwich immunoassay. The microtiter plate provided in this kit has been precoated with a monoclonal antibody specific for HEPC. Standards and samples were then added to the appropriate microtiter plate wells with a biotin-conjugated polyclonal antibody preparation specific for HEPC. Avidin conjugated to Horseradish Peroxidase (HRP) is added to each microplate well and incubated. After substrate solution was added, those wells that contain HEPC, exhibited a change in color proportional to hepcidin concentration in patient serum. The enzyme-substrate reaction was terminated and the color change was measured spectrophotometrically at a wavelength of $450 \mathrm{~nm}$ +or- $10 \mathrm{~nm}$. The observed intensities of duplicate samples were averaged and compared to the curve derived from a serial dilution series of known hepcidin standards $(0-4,000 \mathrm{pg} / \mathrm{ml})$; observed intensities above the standard range were re-analyzed after further sample dilution.

\section{Statistical analysis :}

Data were fed to the computer using the Predictive Analytics Software (PASW Statistics 18). Qualitative data were described using number and percent. Quantitative data were described using median, minimum and maximum as well as mean and standard deviation.

The distributions of quantitative variables were tested for normality using Kolmogorov-Smirnov test, Shapiro-Wilk test. D'Agstino test was used if there was a conflict between the two previous tests. If it reveals normal data distribution, parametric tests was applied. If the data were abnormally distributed, non-parametric tests were used.

For abnormally distributed data, Mann-Whitney Test (for data distribution that was significantly deviated from normal) were used to analyze two independent population. If more than two population were analyzed Kruskal Wallis test to be used. Wilcoxon signed ranks test was used to compare between the different periods. Correlations between two quantitative variables were assessed using Spearman coefficient. Significance test results are quoted as two-tailed probabilities. Significance of the obtained results was judged at the $5 \%$ level.

\section{RESULTS}

The base line characteristics for the initially studied 35 cases (23 males and 12 females) are shown in table1,showing slightly elevated AST (SGOT) and alkaline phosphatase (ALP). While ALT (SGPT), albumin, bilirubin and $\mathrm{Hb}$ levels were within normal range.

As regards the baseline viral load for all 35 studied cases; twenty four $(68.6 \%)$ cases were found to have low viral load (serum HCV RNA $<600,000 \mathrm{IU} / \mathrm{ml})$, two $(5.7 \%)$ cases had a moderate viral load (serum HCV RNA between 600.000$800.000 \mathrm{IU} / \mathrm{ml})$, and nine $(25.7 \%)$ cases had a high viral load (serum HCV RNA $>800,000$ IU/ml).

The degree of liver fibrosis according to Metavir scoring system among the 35 studied cases was as follows; $16(45.7 \%)$ cases were F1, $14(40 \%)$ cases were F2 and only $5(14.3 \%)$ cases were F3. No statistically significant relation was found $(\mathrm{P}=0.318)$ between the degree of liver fibrosis and the viral load. Also no statistically significant relation was found between viral load and liver enzymes (ALT \& AST) $\quad(\mathrm{P}=0.367 \quad \& \quad 0.587$ respectively).

\section{Follow up of cases during the first 24 weeks of therapy :}

The 35 cases studied, were followed up by measuring their viral load initially, at 12 weeks then at 24 weeks during the course of therapy. Thirty $(85.7 \%)$ cases out of the 35 showed an early virologic response EVR. While the remaining $5(14.3 \%)$ cases failed to respond to therapy (non responders) and were excluded from the treatment program and thus from the study.

Out of the 30 cases that achieved EVR and continued therapy, $24(80 \%)$ cases showed response to treatment and undetectable RNA at week 24 of ongoing therapy and continued therapy according to the national guidelines [20]. While the remaining $6(20 \%)$ cases had detectable RNA and they were considered break through cases. So out of the $35(100 \%)$ initially studied cases eleven (31.4\%) (5 non responders and 6 break through cases) did not respond to therapy. 


\section{Serum Hepcidin measurement :}

Serum hepcidin was measured for all the 30 cases that achieved EVR including responders $(n=24)$ and break through cases $(n=6)$ at baseline, 12 and 24 weeks during therapy. Where both groups showed rise in hepcidin level, with no statistically significant difference between both groups $(\mathrm{p}$ at base line $=0.938, \mathrm{p}$ at 3 months $=$ 0.775 and $\mathrm{p}$ at 6 months $=0.186$ ) as shown in table (2).

Yet there was a statistically significant rise in the hepcidin level in responding cases from baseline to 12 weeks of therapy $(\mathrm{P} 1=0.001)$ and from baseline to 24 weeks of therapy $(\mathrm{P} 2<0.001)$ (Table 2, Fig. 1). While the break through cases had no statistically significant rise during the period from baseline to 12 weeks of therapy (P1= 0.058) which later showed a statistically significant rise from baseline to 24 weeks of therapy $(\mathrm{P} 2=0.046)$ and the rise from 12 to 24 weeks was insignificant for both groups $(\mathrm{P} 3$ for responders $=0.841, \mathrm{P} 3$ for break through cases $=$ 0.075) (Table 2, Fig. 2).

In other words this significant rise was demonstrated early in the responding cases at 12 weeks of therapy $(\mathrm{P} 1=0.001, \mathrm{P} 2<0.001)$, while the break through cases showed hepcidin level significant rise only later on at 24 weeks of therapy $(\mathrm{P} 1>0.05, \mathrm{P} 2=0.046)$
Table (3) shows the baseline hepcidin level of both the 30 studied cases and the 15 control group of chronic $\mathrm{HCV}$ patients not under interferon therapy, with no statistically significant difference in serum hepcidin level detected between both groups $(\mathrm{P}=0.555)$, yet when the comparison was done again after 24 weeks of ongoing therapy, a statistically significant rise in hepcidin level in the study group occurred after receiving treatment $(\mathrm{P}<0.001)$.

Baseline viral load and baseline hepcidin concentration for the 30 EVR cases :

The 30 studied cases had variable hepcidin levels regardless of their viral load levels (Table 4) as there was no significant correlation between baseline viral load and baseline hepcidin levels $(\mathrm{P}=0.650)$.

Yet with ongoing therapy a statistically significant negative correlation $\left(\mathrm{P}=0.013^{*}\right)$ between viral load and increased hepcidin level in the responding cases with therapy was found (Fig. $3)$. On the contrary for the breakthrough cases, although these patients were positive for $\mathrm{HCV}$ RNA, and still showed a rise in their hepcidin level, but this rise did not give a statistically significant correlation with the viral load $(\mathrm{P}=$ 0.156) (Fig. 4).

Table (1) : Routine laboratory investigations of the 35 studied cases

\begin{tabular}{|l|c|c|c|}
\hline \multicolumn{1}{|c|}{ Test (normal range) } & Min. - Max. & Mean \pm SD & Median \\
\hline ALT $(7-40 \mathrm{IU} / \mathrm{L})$ & $10.0-82.0$ & $34.66 \pm 15.02$ & 31.0 \\
\hline AST $(5-35 \mathrm{IU} / \mathrm{L})$ & $8.0-118.0$ & $47.46 \pm 25.63$ & 41.0 \\
\hline ALP $(44-147 \mathrm{IU} / \mathrm{L})$ & $60.0-212.0$ & $144.26 \pm 37.46$ & 147.0 \\
\hline Albumin $(3.4-5.4 \mathrm{mg} / \mathrm{dl})$ & $3.20-5.0$ & $4.37 \pm 0.41$ & 4.40 \\
\hline Billirubin $(0.2-1.2 \mathrm{mg} / \mathrm{dl})$ & $0.50-2.10$ & $0.85 \pm 0.35$ & 0.80 \\
\hline $\begin{array}{l}\text { Hb } \\
\text { (males: } 13.8-17.2 \mathrm{~g} / \mathrm{dl}) \\
\text { (females: } 12-15 \mathrm{~g} / \mathrm{dl})\end{array}$ & $11.0-15.60$ & $13.63 \pm 1.17$ & 13.70 \\
\hline
\end{tabular}


Table (2) : Relation between responders and break through cases with hepcidin at different periods of therapy (measured by $\mathrm{pg} / \mathrm{ml}$ )

\begin{tabular}{|c|c|c|c|}
\hline Hepcidin base line & $\begin{array}{c}\text { Responders } \\
(\mathrm{n}=\mathbf{2 4})\end{array}$ & $\begin{array}{l}\text { Break through cases } \\
(\mathrm{n}=6)\end{array}$ & $\begin{array}{c}\text { Total } \\
(\mathbf{n}=\mathbf{3 0})\end{array}$ \\
\hline $\begin{array}{l}\text { Min. - Max. } \\
\text { Mean } \pm \text { SD } \\
\text { Median } \\
\quad \text { P }\end{array}$ & $\begin{array}{c}5.0-257.50 \\
105.94 \pm 96.48 \\
73.50\end{array}$ & $\begin{array}{c} \\
7.0-234.0 \\
104.58 \pm 99.30 \\
87.50 \\
38\end{array}$ & $\begin{array}{c}5.0-257.50 \\
105.67 \pm 95.30 \\
75.0\end{array}$ \\
\hline Hepcidin at 3m & & & \\
\hline $\begin{array}{l}\text { Min. - Max. } \\
\text { Mean } \pm \text { SD } \\
\text { Median } \\
\end{array}$ & $\begin{array}{c}30.0-263.0 \\
171.27 \pm 74.68 \\
172.0\end{array}$ & $\begin{array}{c}10.0-260.0 \\
151.17 \pm 101.84 \\
183.25 \\
75\end{array}$ & $\begin{array}{c}10.0-263.0 \\
167.25 \pm 79.23 \\
172.0\end{array}$ \\
\hline \multicolumn{4}{|l|}{ Hepcidin at $6 \mathrm{~m}$} \\
\hline $\begin{array}{l}\text { Min. - Max. } \\
\text { Mean } \pm \text { SD } \\
\text { Median }\end{array}$ & $\begin{array}{c}31.0-260.50 \\
175.11 \pm 68.0 \\
177.0\end{array}$ & $\begin{array}{c}88.0-280.0 \\
213.58 \pm 69.13 \\
230.0\end{array}$ & $\begin{array}{c}31.0-280.0 \\
182.81 \pm 68.82 \\
194.25\end{array}$ \\
\hline $\begin{array}{l}\mathbf{P} \\
\mathbf{p}_{1} \\
\mathbf{p}_{2} \\
\mathbf{p}_{3}\end{array}$ & $\begin{array}{c}0.001^{*} \\
<0.001^{*} \\
0.841\end{array}$ & $\begin{array}{c}0.058 \\
0.046^{*} \\
0.075 \\
\end{array}$ & \\
\hline
\end{tabular}

$\mathrm{p}_{1}: \mathrm{p}$ value for Wilcoxon signed ranks test between Hepcidin base line and at $3 \mathrm{~m}$

$\mathrm{p}_{2}: \mathrm{p}$ value for Wilcoxon signed ranks test Hepcidin base line and at $6 \mathrm{~m}$

$\mathrm{p}_{3}: \mathrm{p}$ value for Wilcoxon signed ranks test $3 \mathrm{~m}$ and $6 \mathrm{~m}$

*: Statistically significant at $\mathrm{p} \leq 0.05$

Table (3): Comparison of hepcidin between control group and cases at baseline and after 24 weeks of ongoing therapy(measured by $\mathrm{pg} / \mathrm{ml}$ )

\begin{tabular}{|l|c|c|c|}
\hline Hepcidin & $\begin{array}{c}\text { Control } \\
(\mathbf{n = 1 5})\end{array}$ & $\begin{array}{c}\text { Cases } \\
(\mathbf{n = 3 0})\end{array}$ & P \\
\hline At base line & $20.0-201.0$ & $5.0-257.50$ & \\
$\quad$ Min. - Max. & $68.90 \pm 43.21$ & $105.67 \pm 95.30$ & 0.555 \\
Mean \pm SD & 60.0 & 75.0 & \\
Median & $11.0-202.0$ & $31.0-280.0$ & $<0.001^{*}$ \\
\hline At 6 months & $65.20 \pm 45.91$ & $182.81 \pm 68.80$ & \\
Min. - Max. & 55.0 & 194.25 & \\
Mean \pm SD & & \\
Median & &
\end{tabular}

P: $p$ value for Mann Whitney test

*: Statistically significant at $\mathrm{p} \leq 0.05$

Table (4) : Relation between baseline viral load and baseline hepcidin(measured by $\mathrm{pg} / \mathrm{ml}$ ) concentration for 30 EVR cases

\begin{tabular}{|l|c|c|c|c|}
\hline & \multicolumn{3}{|c|}{ Baseline Viral load } & \multirow{2}{*}{ P } \\
\cline { 2 - 4 } & $\begin{array}{c}\text { Low } \\
(\mathbf{n = 2 1})\end{array}$ & $\begin{array}{c}\text { Moderate } \\
(\mathbf{n = 1})\end{array}$ & $\begin{array}{c}\text { High } \\
(\mathbf{n = 8})\end{array}$ & \\
\hline Hepcidin base line & & & & \\
Min. - Max. & $5.0-257.50$ & $53.0-53.0$ & $7.0-203.0$ & \multirow{2}{*}{0.650} \\
Mean \pm SD & $117.77 \pm 102.89$ & $53.0 \pm-53.50$ & $80.41 \pm 76.32$ & \\
Median & 75.0 & 53.0 & 63.50 & \\
\hline
\end{tabular}

p: $p$ value for Kruskal Wallis test 


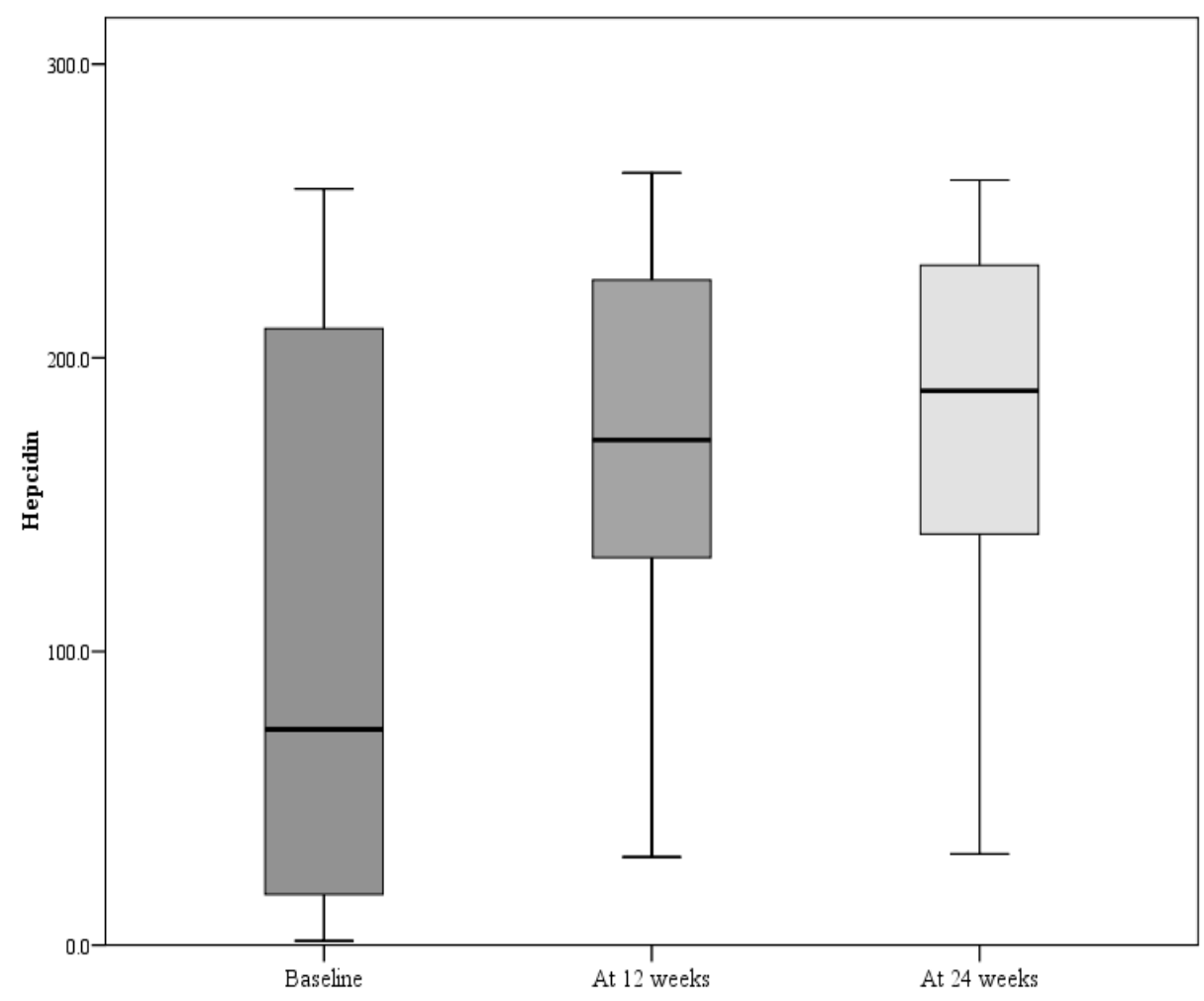

Fig. (1) : Hepcidin concentration of the 24 responding cases at different periods.

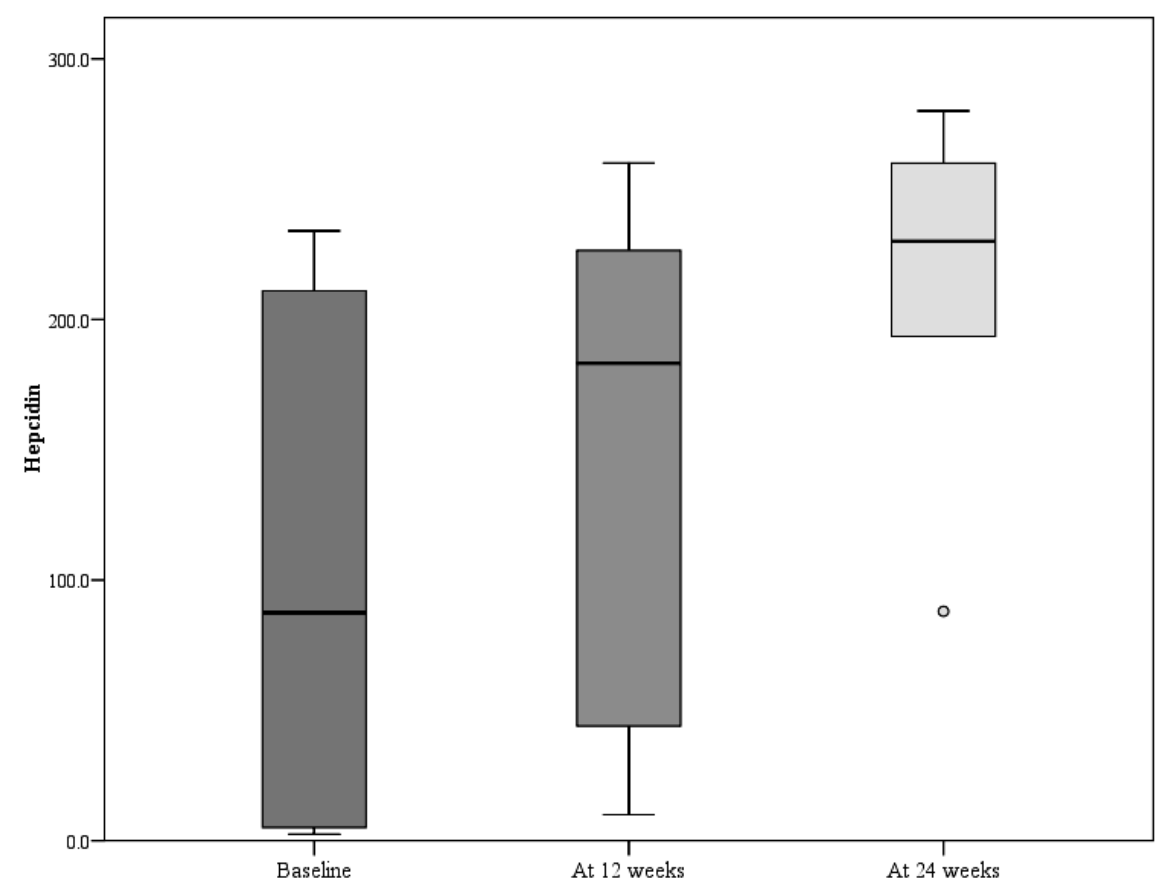

Fig. (2) : Hepcidin concentration for the 6 break through cases at different periods 


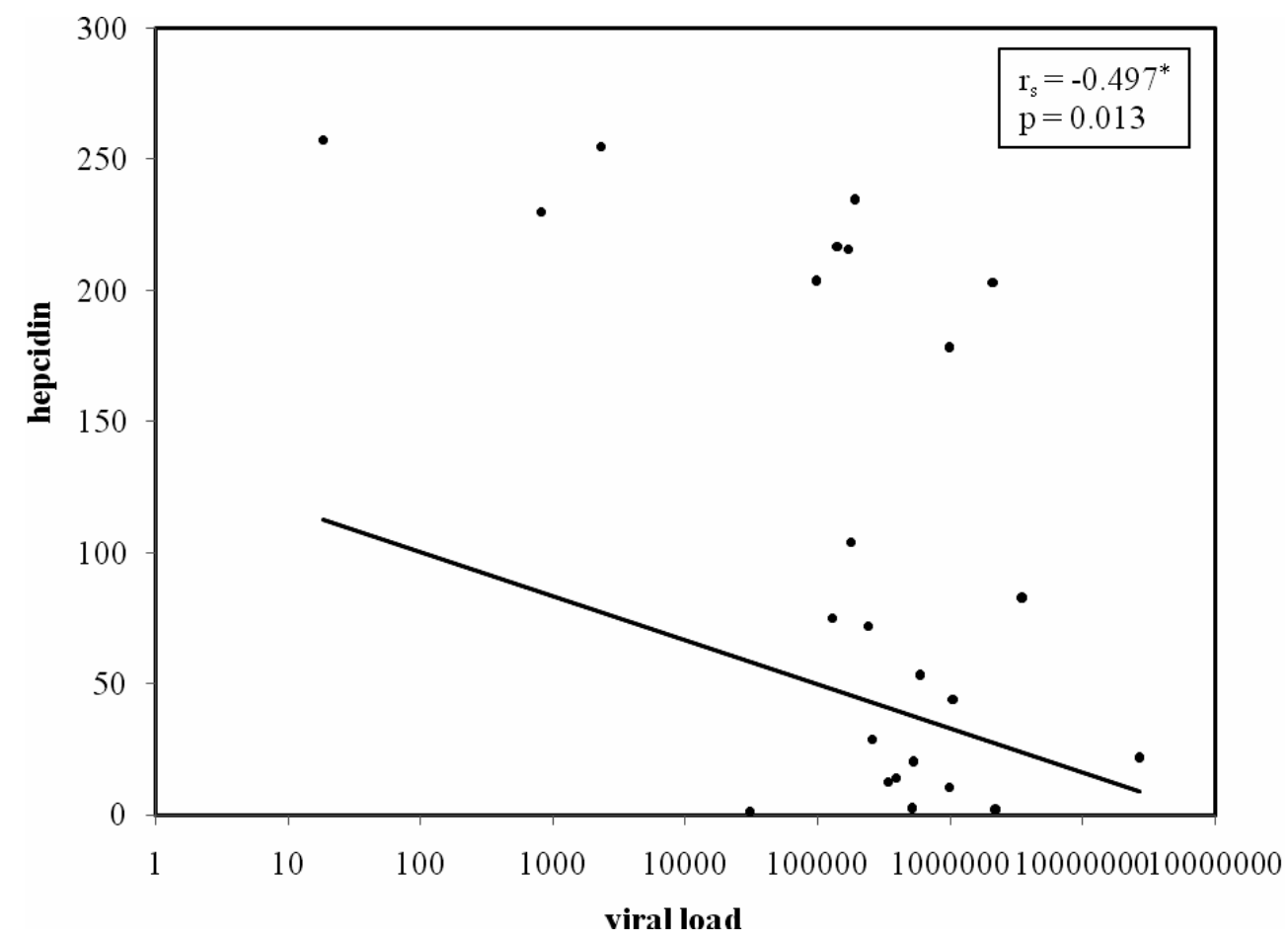

Fig. (3) : Correlation between viral load and hepcidin concentration of the 24 responding cases

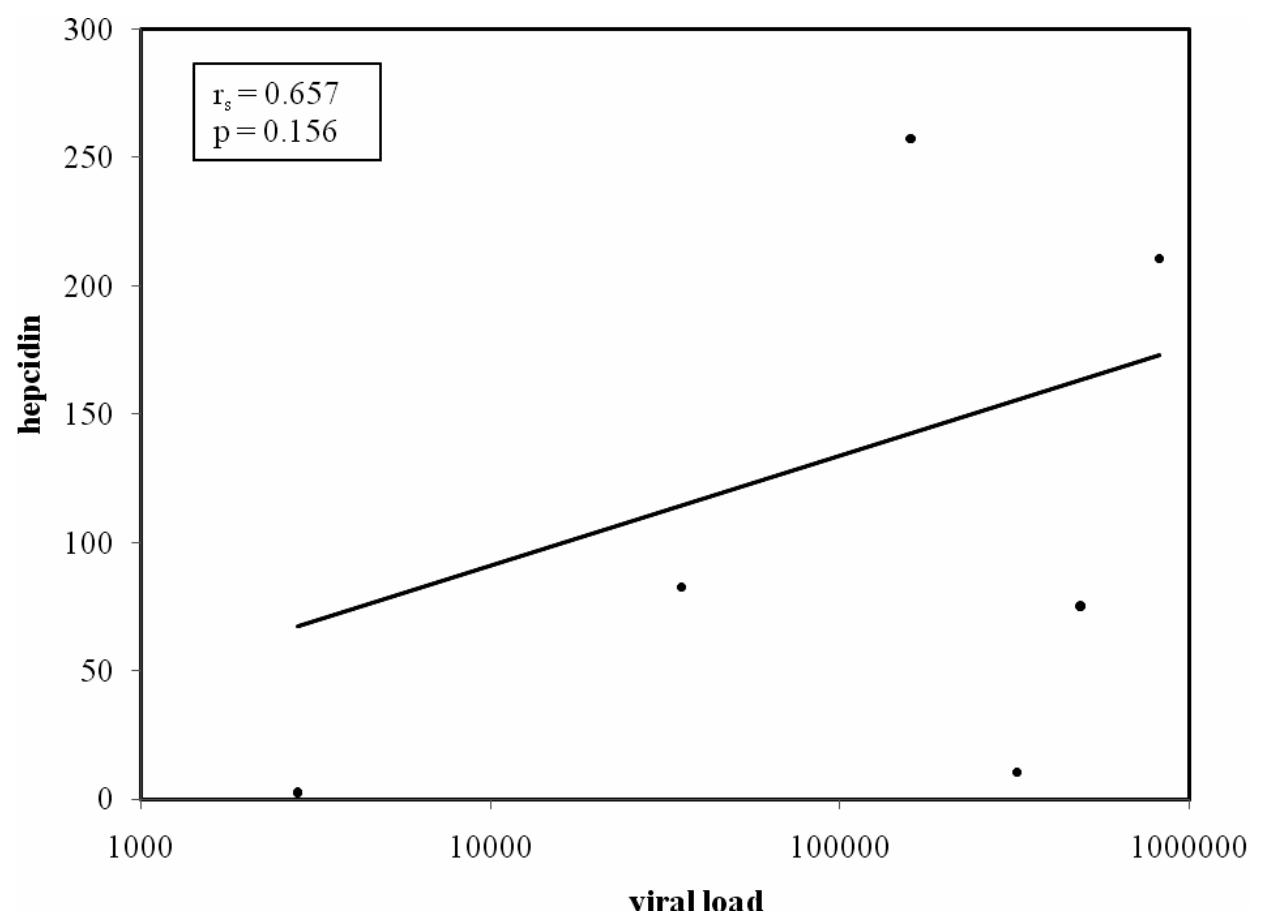

Fig. (4) : Correlation between viral load and hepcidin concentration of the 6 breakthrough cases 


\section{DISCUSSION}

Regarding the sex distribution of the studied cases males were predominant, although patients' selection was fairly random. This is in agreement with the study conducted in the National Research Center, Cairo Egypt by Moataza H. Omran et al. [24] such observation is partly related to social risk factors for $\mathrm{HCV}$ transmission as drugs, schistosomiases and occupational exposure $[26,27]$.

Real time RT-PCR was mandatory done for all patients as a prerequisite before starting PEGIFN and RBV combination therapy with no significant correlation found between viral load and degree of liver fibrosis in the present study $(\mathrm{P}=0.318)$, as also reported by other several studies $[28,29,30]$, where the serum HCV-RNA titer did not reflect the grades of liver necroinflammatory activity and the stage of liver fibrosis, and this was attributed to the fact that the mechanism of liver damage caused by HCV is still not clear whether it's either due to direct damage by HCV or immune-mediated hepatic injury induced by $\mathrm{HCV}$.

Also in the present study no statistically significant correlation between viral load and liver enzymes ALT and AST ( $\mathrm{P}=0.367,0.587$ respectively). This was in concordance with Luay Ein [31] and Anand et al. [29] who observed no correlation between HCV viral load, and serum ALT and AST values.

In the present study the viral load of the 35 cases was assessed again at 12 weeks of therapy to evaluate EVR which is defined as undetectable or at least a 2-log decrease in HCV RNA, and the results showed that $30(85.7 \%)$ patients achieved EVR, and the remaining $5(14.3 \%)$ cases were non responders and thus were excluded from the treatment project.

In a study done by Gary et al. [32], it was detected that those patients who failed to achieve EVR after 12 weeks had no chance of reaching SVR, even if they completed the additional 9 months of treatment that was originally prescribed. Also they found that not all patients who had EVR ultimately achieved SVR. Where, SVR was also lower in patients who had a 2-log decrease in the HCV RNA level but remained PCR positive than in those who had undetectable HCV RNA by PCR after 12 weeks. Another factor that explains the failure of patients with EVR to reach SVR is the ability to adhere to the prescribed treatment regimen, as the reduction of PEG-
IFN/RBV therapy or premature discontinuation in the first 12 weeks markedly reduces the chance of SVR.

Also in our study out of the 30 cases who achieved EVR and thus continued therapy, viral load was reassessed at 24 weeks during therapy and resulted in undetectable viral RNA in 24 $(80 \%)$ cases, and detection of HCV RNA in the remaining $6(20 \%)$ cases which were considered break through cases. So, out of the 35 initially studied cases, $11(31.4 \%)$ (5 non responders and 6 break through cases) did not respond to therapy. This was matching with the reported treatment failure rate for genotype $4(50 \%-21 \%)[33,34,35]$.

Hepcidin is a recently discovered iron regulatory hormone, it is synthesized predominantly in the liver. Synthesis of hepcidin is increased by iron overload and decreased by anemia and hypoxia. Moreover, it is also induced by infection and inflammation [36].

In our study hepcidin hormone concentration was measured for the 30 studied cases before starting therapy, at 12 weeks and at 24 weeks during ongoing therapy, and we found a significant rise in hepcidin level at different periods among all patients including the $24(80 \%)$ responding cases and the $6(20 \%)$ break through cases. This significant rise was demonstrated early in the responding cases at 12 weeks of therapy $(\mathrm{P} 1=$ $0.001, \mathrm{P} 2<0.001$ ), while the break through cases showed hepcidin level significant rise only later on at 24 weeks of therapy (P1>0.05, P2=0.046)

Similar to our findings Ryan et al. [37] reached a conclusion that the hepcidin induction occurs following the initiation of PEG-IFN-a treatment for HCV associated with decrease in serum iron, and was greatest in those with the most significant decline in viral load as in the present study as it was found that chronic HCV represents a complex condition for hepcidin regulation. As inflammation and iron overload have a stimulatory effect on hepcidin expression, while HCV induced oxidative stress suppresses hepcidin expression [37].

In our study the correlation between the viral load and hepcidin level of the $6(20 \%)$ break through cases before and at 24 weeks during the course of therapy showed that, although these patients turned positive in their RT-PCR assessment, they still showed a significant rise in their hepcidin level. However, there was no statistically significant relation between their viral load and hepcidin levels $(\mathrm{P}=0.156)$. 
On the other hand, hepcidin hormone concentration was measured for 15 chronic $\mathrm{HCV}$ patients not under therapy as control group. A correlation between the baseline hepcidin concentration of the 30 cases included in the study and the control group, was done with no significant difference detected in serum hepcidin levels between both groups $(\mathrm{P}=0.555)$. While the comparison between hepcidin concentration in control group and responding cases at 24 weeks of ongoing therapy showed a significant rise of hepcidin level after receiving treatment $(\mathrm{P}<0.001)$.

Regarding the 24 (80\%) cases that showed response to treatment, the correlation between their viral load and hepcidin levels before and at 24 weeks of therapy showed that the viral RNA disappeared after 24 weeks of therapy and the hepcidin concentration was significantly increased. There was a statistically significant negative relation between their viral load and hepcidin concentration $(\mathrm{P}=0.013)$.

Recently, experimental evidence from cultured $\mathrm{HCV}$ infected cell lines as well as from HCVinfected mice suggested that hepcidin expression is down-regulated in HCV infection. Oxidative stress in the form of reactive oxygen species was responsible for the hepcidin suppression through increased histone deacetylase activity. Their findings support the in vitro evidence of $\mathrm{HCV}$ induced hepcidin suppression, and suggest that $\mathrm{HCV}$ infection down-regulates serum hepcidin, while increasing inflammation and/or fibrosis tend to restore its levels. Also in vitro studies have suggested that weekly PEG-IFN-a administration led to hepcidin induction of benefit to $\mathrm{HCV}$ patients [37,38]. Thus if interferon free regimes are to be approved for future therapy studies can be planed to separate out the effect of interferon from directly acting anti-viral drugs on hepcidin.

This was in agreement with the study of Naoki Fujita et al. [39] that measured serum hepcidin before and after the completion of 48-week course of PFG-IFN plus ribavirin therapy in 27 chronic HCV patients. Twelve patients were assigned to SVR and the remaining 15 to nonSVR, and serum hepcidin was measured again 24 weeks after completing therapy. After the PEGIFN plus ribavirin therapy, serum hepcidin levels were significantly increased in SVR patients, but on the contrary to our study, hepcidin decreased significantly in non-SVR patients. From these results, relatively low hepcidin expression in chronic HCV patients seems to be directly related to $\mathrm{HCV}$ replication in the liver.

We studied the relation between hepcidin levels and degree of liver fibrosis and we noticed that there is no significant correlation between baseline hepcidin concentration of the 30 studied cases and degree of liver fibrosis $(\mathrm{P}=0.407)$. The mean baseline hepcidin level for $\mathrm{F} 1$ cases was $126.31 \pm 98.37$, for $\mathrm{F} 2$ cases was $76.58 \pm 83.62$, and for $\mathrm{F} 3$ cases $137.38 \pm 114.53$

This was matching with the results of Aoki's reports [40], the histological grading were not significantly correlated with serum hepcidin in chronic $\mathrm{HCV}$, mild and local inflammation which occurred in the liver of CHC may not induce hepcidin expression as $\mathrm{P}=0.2359$. This result was also supported by a study conducted by Usama et al. [41], which revealed that there was no significant correlation between serum prohepcidin which is a hepcidin precursor and hepatic fibrosis or inflammatory activity according to Metavir Scoring System in CHC patients.

In contrast, in 2010 the study of Tsochatzis et al. [38] in which the serum hepcidin levels were found to positively correlate with both necroinflammation $(\mathrm{r}=0.259, \mathrm{P}=0.011)$ and fibrosis $(\mathrm{r}=0.214, \mathrm{P}=0.036)$. Moreover, serum hepcidin levels increased with increasing severity of fibrosis $(\mathrm{P}=0.048)$.

We also studied the relation between liver enzymes (ALT, AST) and baseline hepcidin levels for the 30 studied cases and we found there was no significant correlation between hepcidin levels and liver enzymes ALT and AST $(\mathrm{P}=0.332$, 0.624 respectively).

In agreement with our results, Fujita et al. [39] found that there were no significant correlations between serum hepcidin levels and serum transaminase (AST and ALT). Similarly, Aoki et al. [40] demonstrated that among patients with hepatitis $\mathrm{C}$, hepcidin mRNA expression in the liver did not correlate with aspartate aminotransferase and alanine aminotransferase. Also Elhamy et al. [42] has found no significant correlation between the expression of hepcidin mRNA and liver enzymes (ALT, AST).

In contrast, Tsochatzis et al. [38] concluded that in patients with chronic HCV, serum hepcidin correlated positively with aspartate aminotransferase (AST) and with alanine aminotransferase (ALT). 


\section{CONCLUSION}

From the current study we can conclude that chronic $\mathrm{HCV}$ is associated with reduced level of serum hepcidin, however this reduced level is fully reversible with IFN/RBV therapy. Also the initial rise of serum hepcidin could be used as an indicator of patients response to therapy although we recommend a wider scale study (regarding patients numbers and duration) for a better understanding of the prognostic and monitoring role of hepcidin among chronic HCV patients on antiviral therapy.

\section{Ethical approval: Approved.}

\section{Funding: None.}

\section{Conflict of interest: None.}

\section{REFERENCES}

1. World Helath organization (WHO). Global surveillance and control of hepatitis $\mathrm{C}$ Report of a WHO consultation organized in collaboration with the viral hepatitis Prevention Board, Antwerp, Belgium. J Viral Hepat 2001; 6:35-47.

2. Alter MJ, Kruszon-Moran D, Nainan OV, McQuillan GM, Gao F, Moyer LA, Kaslow RA, Margolis HS. The prevalence of hepatitis $\mathrm{C}$ virus infection in the United States, 1988 through 1994. N EnglJMed 1999; 341:556-562.

3. Centers for Disease Control and Prevention. Progress toward Prevention and Control of Hepatitis C Virus Infection - Egypt, 2001-2012.MMWR 2012; 61 (29):545, 546.

4. Feld JJ and Liang TJ. Hepatitis C-identifying patients with progressive liver injury. Hepatology 2006;43: 194-206.

5. Marcellin P Hepatitis C: clinical spectrum of the disease. JHepatol 1999; 31 Suppl. 1: 9-16.

6. Zein N. Clinical significance of hepatitis $\mathrm{C}$ virus genotypes. Clinical Microbiology Reviews 2000; 13: 223-235.

7. Ellis G, Goldberg DM, Spooner RJ, Ward MA. Serum enzyme tests in diseases of liver and biliary tree. Am JClinPathol1998;70: 248-258.

8. Kanda J, Mizumoto C, Kawabata H, Tsuchida H, Tomosugi N, Matsuo K, Uchiyama T Serum hepcidin level and erythropoietic activity after hematopoietic stem cell transplantation. Haematologica 2008; 93: 1550-1554.

9. Hoppe M, Lönnerdal B, Hossain B, Olsson S, Nilsson F, Lundberg PA, Rödjer S, Hulthén L. Hepcidin, interleukin-6 and hematological iron markers in males before and after heart surgery. $J$ Nutr Biochem 2009; 20: 11-16.

10. Politou M, Papanikolaou G .Hepcidin: A key iron regulator involved in the pathogenesis of anaemia of chronic disease. Haema 2004; 7: 165-174.
11. Nicoras G, Viatte L, Bennoun M, Beaumont C, Kahn A, Vaulont S. Hepcidin. A new iron regulatory peptide. Blood Cells Mol. Di 2002; 29:327-335.

12. Ganz T. Hepcidin : a key regulator of iron metabolism and mediator of anemia of inflammation. Blood 2003;102:783-788.

13. Nemeth E, Tuttle MS, Powelson J, Vaughn MB, Donovan A, Ward DM, Ganz T, Kaplan J. Hepcidin regulates iron efflux by binding to ferroportin and inducing its internalization. Science 2004; 306:2090-2093.

14. Nicolas G, Chauvet C, Viatte L, Danan JL, Bigard $\mathrm{X}$, Devaux I, Beaumont C,Kahn A, Vaulont $\mathrm{S}$. The gene encoding the iron regulatory peptide hepcidin is regulated by anemia, hypoxia, and inflammation. J. Clin. Invest 2002;110:10371044.

15. Nemeth E, Rivera S, Gabayan V, Keller C, Taudorf S, Pedersen BK, Ganz T. IL-6mediates hypoferremia of inflammation by inducing the synthesis of the iron regulatory hormone hepcidin. J. Clin. Invest 2004;113:1271-1276.

16. Metwally MA, Zein CO, Zein NN. Clinical significance of hepatic iron deposition and serum iron values in patients with chronic hepatitis C infection. Am. J. Gastroenterol 2004;99:286-291.

17. Tharburn D, Curry G, Spooner R, Spence E, Oien K, Halls D, Fox R, McCruden EAB, MacSween RNM, Mills PR. The role of iron and haemochromatosis gene mutations in the progression of liver disease in chronic hepatitis C. Gut 2002; 50:248-252.

18. Tung BY, Emond MJ, Bromer MP, Raaka SD, Cotler SJ, Kowdley KV. Hepatitis C, iron status, and disease severity: relationship with HFE mutations. Gastroenterology 2003;124:318-326.

19. Krause A, Neitz S, Mägert HJ, Schulz A, Forssmann WG, Schulz-Knappe P, Adermann K. LEAP-1, a novel highly disulfide-bonded human peptide, exhibits antimicrobial activity. FEBS Lett 2000; 480: $147-150$.

20. Arab Republic of Egypt, Ministry of Health and Population National Committee for the Control of Viral Hepatitis. Egyptian national control strategy for viral hepatitis 2008-2012.

21. Bain BJ, Lewis SM, Bates I Basic hematological techniques. In: Lewis SM, Bain BJ, Bates I, editors. Dacie and Lewis practical hematology. $10^{\text {th }} \mathrm{ed}$. Elsevier Ltd Germany 2006;25-53 p.

22. Roche Molecular Systems, Inc COBAS AmpliPrep/COBAS TaqMan HCV Test (Package Insert) Branchburg, NJ(2008).

23. Ganz T, Olbina G, Girelli D, Nemeth E, Westerman M.Immunoassay for human serum hepcidin. Blood journal 2012;112: 4292-4297.

24. Cheng PP, Jiao XY, Wang XH, Lin JH, Cai YM.Hepcidin expression in anemia of chronic disease and concomitant iron-deficiency anemia.ClinExp Med 2011;11:33-42. 
25. Moataza H O, Samar S Y, Wael T, Ashraf A, Noha G, Khaled A, Wael N, Mostafa K. Phylogenetic and Genotyping of Hepatitis C Virus in Egypt. Australian Journal of Basic and Applied Sciences 2009;3(1): 1-8.

26. Waked I, Saleh S, Moustafa A, Raouf A, Thomas D. High prevalence of hepatitis $\mathrm{C}$ in Egyptian patients with chronic liver disease. Gut 1995;37: 105-107.

27. Frank C, Mohamed M, Strickland G, Lavanchy D, Arthur R, Magder LS, El Khoby T, AbdelWahab Y, Aly Ohn ES, Anwar W, Sallam I. The role of parental antischistosomal therapy in the spread of hepatitis $\mathrm{C}$ virus in Egypt. Lancet 2000;11(355): 887-891.

28. MCguinness PH, Bishop GA, Painter DM, Raymond C, MCcaughan GW. Intrahepatic Hepatitis C RNA Levels Do Not Correlate With Degree of Liver Injury in Patients With Chronic Hepatitis C. Hepatology 1996;23(4):676-687.

29. Anand BS, Velez M. Assessment of correlation between serum titers of hepatitis $\mathrm{C}$ virus and severity of liver disease. World J Gastroenterol 2004; 10(16):2409-2411.

30. Pei L, Ying L, Cui-ming S. Correlations of Serum Hepatitis C Virus RNA and Alanine Transaminase with Liver Histopathological Changes in Patients With Chronic Hepatitis C. Labmedicine 2009; 40(3):167-169

31. Lauy E, Khitam R, Suhair A, Safa A, Raghad J. Serum HCV-RNA levels in patients with chronic hepatitis C: correlation with histological features. Arab Journal of Gastroenterology 2009; 10(1) : 10-13.

32. Gary LD, John BW, John GM, Michael PM, Joann H, Albrecht J. Early Virologic Response to Treatment With Peginterferon Alfa-2b plus Ribavirin in Patients With Chronic Hepatitis C. Hepatology 2003;38(3):645-652.

33. Derbala MF, Al Kaabi SR, El Dweik NZ, Pasic F, Butt MT, Yakoob R, Al-Marri A, Amer AM, Morad $\mathrm{N}$, Bener. A Treatment of Hepatitis $\mathrm{C}$ virus genotype 4 with peginterferonalfa-2a: impact of bilharziasis and fibrosis stage. World J Gastroenterol 2006; 12: $5692-5698$.

34. Trapero M M, Moreno M JA, Garcia B ,Borque MJ, Medina J,Garcia-Sanchez A, Moreno-Otero R. Clinical and pathological characteristics and response to combination therapy of genotype 4 chronic hepatitis $\mathrm{C}$ patients: experience from a spanish center. J Chemother 2007; 9:423-427.

35. El Zayadi AR, Attia M, Barakat EM, Badran HM, Hamdy H, El-Tawil A, El-Nakeeb A, Selim $\mathrm{O}$, Saied. A Response of hepatitis C genotype-4 naive patients to 24 weeks of peg-interferon-a2b/ ribavirin or induction-dose interferon $a 2 b /$ ribavirin/amantadine: a non-randomized controlled study. Am J Gastroenterol 2005;100: 2447-2452.

36. Jaroszewicz J, Rogalska M, Flisiak I, Flisiak R. Successful antiviral therapy is associated with a decrease of serum prohepcidin in chronic hepatitis $\mathrm{C}$. World J Gastroenterol 2010;16(14): 1747-1752.

37. Ryan JD, Altamura S, Devitt E, Sarah M, Lawless MW, Martina UM, Crowe J. Pegylated Interferon-a Induced Hypoferremia Is Associated With the Immediate Response to Treatment in Hepatitis C. Hepatology 2012;56(2):492-500.

38. Tsochatzis E, Papatheodoridis GV, Koliaraki V, Hadziyannis E, Kafiri G, Manesis EK, Mamalaki A, Archimandritis. Serum hepcidin levels are related to the severity of liver histological lesions in chronic hepatitis C. Journal of Viral Hepatitis 2010; 17: 800-806.

39. Fujita N, Sugimoto R,Motonishi S, Tomosugi N, Tanaka H, Takeo M, Iwasa M, Kobayashi Y, Hayashi H, Kaito M, Takei Y. Patients with chronic hepatitis $\mathrm{C}$ achieving a sustained virological response to peginterferon and ribavirin therapy recover from impaired hepcidin secretion. Journal of Hepatol 2008; 49: 702-710.

40. Aoki CA, Rossaro L, Ramsamooj R, Brandhagen D, Burritt MF, Bowlus CL. Liver hepcidin mRNA correlates with iron stores, but not inflammation in patients with chronic hepatitis C. J ClinGastroenterol 2005;39:71-74.

41. Usama K, Monkez M, Abdullah A, Alsayed Ahmed A, Mahmoud A.Prohepcidin Level Is Decreased In Patients with Chronic Viral C Hepatitis, and Has No Correlation with Disease Progression. Journal of American Science 2012; 8(9):333-337.

42. Elhamy A E, El-Sayed T, Mohamed A F, Amal F, Samah F E, and Somyah S. Hepcidin mRNA Level as A Parameter of Disease Progression in Chronic Hepatitis C and Hepatocellular Carcinoma. Journal of the Egyptian Nat Cancer Ins 2009; 21 : (4) 333-342.

Peer reviewers: Hal Drakesmith, Associate Professor of Immunology, Weatherall Institute of Molecular Medicine, John Radcliffe Hospital/Headley Way, Oxford OX3 9DS ,United Kingdome. Emad A Emam, Pofessor of Internal Medicine and Hepatogastroenterology,Faculty of Medicine, Zagazig University, Egypt.

Editor: Tarik Zaher, Professor of Tropical Medicine and Hepatogastroenterology, Faculty of Medicine, Zagazig University, Egypt. 